\title{
The Prevention of Thalassemia
}

\author{
Antonio Cao ${ }^{1,3}$ and Yuet Wai Kan ${ }^{2}$ \\ ${ }^{1}$ Dipartimento di Scienze Biomediche e Biotecnologie, Università degli Studi di Cagliari, \\ Via Jenner snc 09121 Cagliari, Sardinia, Italy \\ ${ }^{2}$ Department of Medicine, University of California, San Francisco, California 94143-0793 \\ Correspondence: yw.kan@ucsf.edu
}

The thalassemias are among the most common inherited diseases worldwide, affecting individuals originating from the Mediterranean area, Middle East, Transcaucasia, Central Asia, Indian subcontinent, and Southeast Asia. As the diseases require long-term care, prevention of the homozygous state constitutes a major armament in the management. This article discusses the major prevention programs that are set up in many countries in Europe, Asia, and Australia, often drawing from the experience in Sardinia. These comprehensive programs involve carrier detections, molecular diagnostics, genetic counseling, and prenatal diagnosis. Variability of clinical severity can be attributable to interactions with $\alpha$-thalassemia and mutations that increase fetal productions. Special methods taht are currently quite expensive and not widely applicable are preimplantation and preconception diagnosis. The recent successful studies of fetal DNA in maternal plasma may allow future prenatal diagnosis that is noninvasive for the fetus.

$\mathrm{T}_{\mathrm{h}}^{\mathrm{h}}$ he thalassemias are a group of autosomal recessive disorders caused by reduction or absent production of one or more of the globin chains that make up the hemoglobin $(\mathrm{Hb})$ tetramers. According to the type of globin chain involved, two main types, i.e., the $\alpha$ - and $\beta$-thalassemias can be distinguished. In addition, complex thalassemias resulting from defective production of two to four different globin chains $(\delta \beta-, \gamma \delta \beta$-, and $\varepsilon \gamma \delta \beta$-thalassemia) are recognized (Weatherall and Clegg 2001). The clinical types of thalassemias that are targets of prevention are $\beta$-thalassemia major resulting from homozygosity for $\beta$-thalassemia and $\mathrm{Hb}$ Bart's fetal hydrops syndrome caused by deletion or dysfunction of all four $\alpha$-globin genes (Weatherall and Clegg 2001).

\section{EPIDEMIOLOGY AND GLOBAL BURDEN OF THALASSEMIA DISORDERS}

Thalassemias are among the commonest autosomal recessive disorders worldwide (Modell and Darlison 2008; Weatherall 2010a,b) and are prevalent in populations in the Mediterranean area, the Middle East, Transcaucasus, Central Asia, the Indian subcontinent, and the Far East. However, they are also quite common

\footnotetext{
${ }^{3}$ Dr. Kan, the editors, and publisher deeply regret that Professor Antonio Cao, a remarkable contributor to the study and alleviation of thalassemia, passed away on June 21, 2012.

Editors: David Weatherall, Alan N. Schechter, and David G. Nathan

Additional Perspectives on Hemoglobin and Its Diseases available at www.perspectivesinmedicine.org

Copyright (C) 2013 Cold Spring Harbor Laboratory Press; all rights reserved; doi: 10.1101/cshperspect.a011775

Cite this article as Cold Spring Harb Perspect Med 2012;3:a011775
} 
in populations of African heritage. Because of population migration, nowadays thalassemias are also common in Northern Europe, North Central and South America, and Australia.

Worldwide 56,000 conceptions have a major thalassemia disorder of which approximately 30,000 are affected by $\beta$-thalassemia major and 3500 succumb perinatally from the hydrops fetalis syndrome. Most (or many) of these patients are born in developing and low-income countries where they create an enormous health burden. Together with sickle cell anemia, it has also been estimated that, worldwide, 9 million carriers become pregnant annually and 1.33 million pregnancies are at risk for a thalassemia major condition (Modell and Darlison 2008; Weatherall 2010b).

\section{POPULATION CONTROL OF THALASSEMIAS: PROGRAMS FOR PREVENTION}

In the late 1970s pilot population programs directed to prevent $\beta$-thalassemia major by carrier screening, counseling, and prenatal diagnosis started in several at-risk populations in the Mediterranean area [Cyprus, Sardinia, several regions of Continental Italy (Delta Po area, Sicily), and Greece] (Angastiniotis and Hadjiminas 1981; Cao et al. 1996; Loukopoulos 1996). At present, several countries have set up comprehensive national prevention programs, which include public awareness and education, carrier screening, and counseling, as well as information on prenatal diagnosis and preimplantation diagnosis. These countries are Italy, Greece, Cyprus, UK, France, Iran, Thailand, Australia, Singapore, Taiwan, Hong Kong, and Cuba (A Eleftheiou and M Angastionitis, pers. comm.). Partial programs including antenatal screening according to ethnic origin are available in several countries in Northern Europe (Netherlands, Belgium, and Germany) (Modell et al. 2007). In many developing countries, prenatal diagnosis service has also been introduced (Canatan et al. 2006; Chern et al. 2006; Weatherall 2010b).

In most programs, carrier screening and counseling are being performed on a voluntary basis. In Cyprus, however, the Orthodox church requires a certificate proving that screening for $\beta$-thalassemia has been performed before marriage, but allows the final decision on marriage and a reproduction option to be left to the couple (Angastiniotis and Hadjiminas 1981; Kalokairinou 2007). When Cyprus became a member of the European Union in 2004, the requirement for this certification became unnecessary for civil weddings (Kolnagou and Kontoghiorghes 2009). In a number of Muslim countries including Lebanon, Iran, Saudi Arabia, Tunisia, United Arab Emirates, Bahrain, Qatar, and Gaza Strip (Samavat and Modell 2004; Inati et al. 2006), the national premarital programs are mandatory and aimed at limiting carrier marriage. In most of these countries, nowadays, interruption of the pregnancy is permitted for severe fetal disorders but only within the fourth month of gestation. In China, prenatal screening was compulsory to obtain marriage permission by the marriage law office (Li 2009). Because of worldwide criticism, the requirement for a certificate of premarital screening was withdrawn.

One of the obstacles for introducing prospective screening in Continental Europe is the lack of awareness among policymakers, health professionals, and groups at risk, of hemoglobin disorders and the failure to recognize that hemoglobin disorders nowadays present a significant health problem (Modell et al. 2007). In developing countries, it has been suggested that the ideal place where these preventive measures could be organized is through existing health care services. Intensive education of health professionals as well as the population at large in the field of preventive genetics is needed (reviewed in Alwan and Modell 2003) and major health organizations and funding agencies must support these initiatives (Weatherall 2010b).

In $\alpha$-thalassemia, screening is recommended only to detect couples at risk for hydrops fetalis syndrome because severe toxemia complications (hypertension, preeclampsia) in the mother may occur (Chui 2005). So far, screening has been mostly retrospective. But prospective screening has recently been introduced in several South Asian at-risk countries such as 
Hong Kong, Southern China, Thailand, Taiwan, Malaysia, Singapore, Maldives, and Sri Lanka (Premawardhena et al. 2004; A Eleftheiou and M Angastionitis, pers. comm.). Because of the mild phenotype, prevention of $\mathrm{HbH}$ disease is not justified and should be discouraged.

\section{PROGRAMS FOR CONTROL OF $\beta$-THALASSEMIA: EDUCATION}

The successful programs in the Mediterranean area are all characterized by intensive education directed toward the health personnel and to the population at large. Periodic meetings are held among physicians and especially pediatricians and obstetricians, family planning workers, nurses, and social workers, to discuss the clinical characteristics, the natural history, the principles of genetic counseling, and the methodologies for preventing the birth of affected children (Fig. 1). Population education makes use of mass media, posters, and informational booklets, which are left at various key sites such as family planning clinics, marriage registries, and counseling rooms. The essential messages should include the clinical manifestation, natural history, available therapies, and life expec- tancy for the homozygous state of thalassemia major. It is important to emphasize that the carrier state can be easily identified at the thalassemia centers and is not associated with stigmatization, whereas couples who are both carriers have several reproductive options, including prenatal diagnosis. Contact with parents' and patients' associations should be regularly maintained to update them on the content of the messages to avoid potential misinformation. Furthermore, parents' associations can play an invaluable role as an influential group by raising economical support for all aspects of thalassemia management and providing psychological assistance to parents. Furthermore, in several countries, an annual thalassemia meeting or thalassemia day is organized and a specific news magazine is regularly issued.

Formal education on thalassemias was also introduced in the educational curriculum at the end of secondary school (Cao et al. 2008; Kalokairinou 2008; Amato et al. 2009). A critical evaluation of the information channels by which the population was informed, was performed in Sardinia and showed that a large majority of the target population (70\%) was informed via physicians (family doctors, obstetricians, and

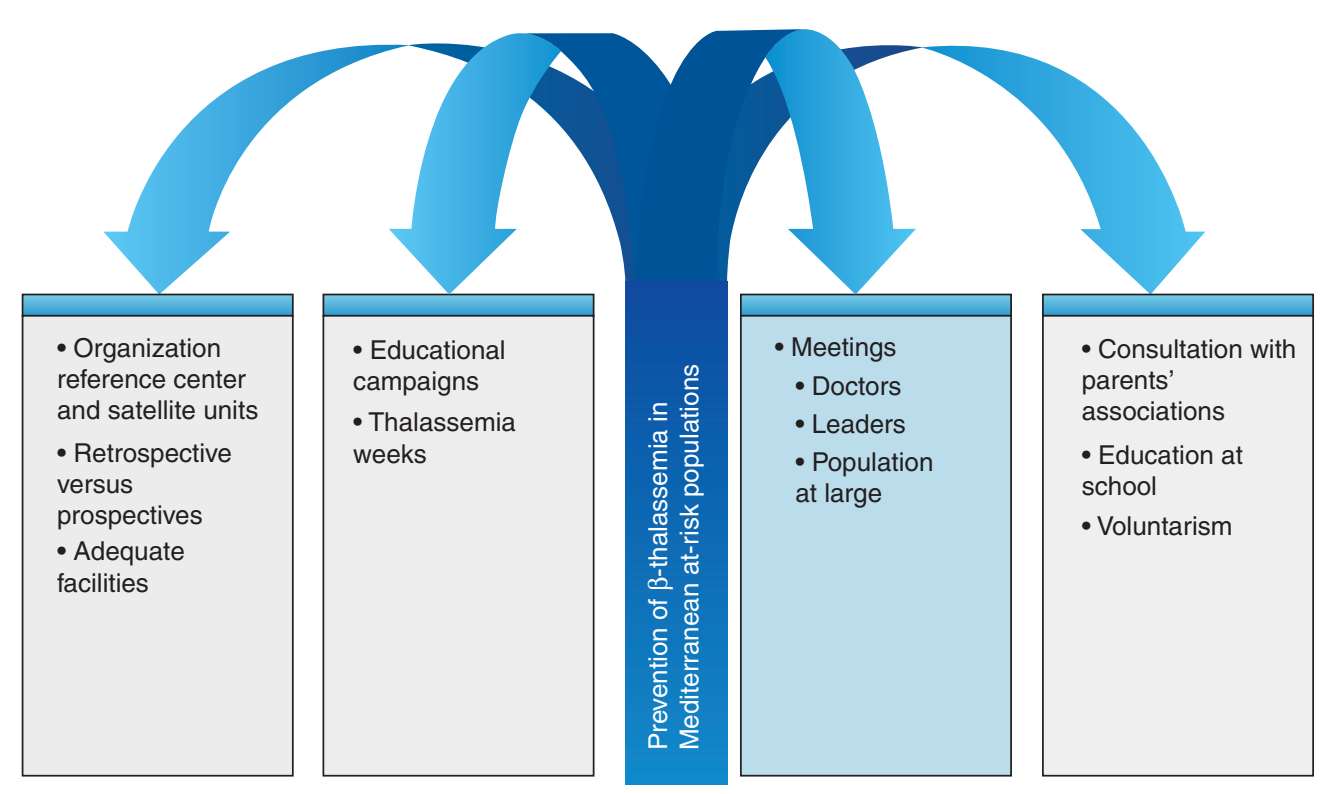

Figure 1. Strategy for prevention of $\beta$-thalassemias in Mediterranean at-risk populations. 
genetic counselors). These programs were initially directed to couples with a previous affected child (retrospective diagnosis). Although very useful for individual families, retrospective diagnosis has a limited effect on the control of homozygous $\beta$-thalassemia at the population level. Nowadays, the target populations for screenings are couples before marriage, at preconception, and early following marriage ( prospective diagnosis). Both in Cyprus and in Italy, the percentage of young unmarried couples requesting screening is increasing, indicating a continuous improvement of the knowledge on thalassemia. In all these programs, carrier screening has been performed on a voluntary basis. Information counseling preceded testing but written informed consent, which should be performed according to accepted principles, is usually not requested.

Another critical prerequisite for a screening program is the organization of adequate facilities to meet the demand both for screening and prenatal diagnosis. In all the successful programs, a large majority of the adults counseled are already fully informed about thalassemia and the methodology for its prevention, and are capable of making an informed decision about reproduction. Furthermore, as seen later, these programs have resulted in a consistent decline in the birth rate of homozygous $\beta$-thalassemia.

In Sardinia, a hub and spokes network with a main center and several satellite units was instrumental in achieving such success. A similar organization has been set up in Cyprus. In Sardinia, the distribution of the population in small villages facilitates the spread of information and extends the counseling and testing to families of carriers and parents. The introduction of teaching on thalassemia in secondary school has also played a critical role in enforcing the knowledge of thalassemia in the family members. Potential economic barriers were prevented by incorporating the screening, counseling, and prenatal diagnosis into the network of the National Health Service. The experience gathered in these preventive programs indicates that population education should be modulated according to the cultural and religious characteristics of the target population.

\section{CARRIER DETECTION}

Heterozygotes for $\beta$-thalassemias, both of the $\beta^{0}$ or the $\beta^{+}$variety are characterized hematologically by high red blood cell count, microcytosis, hypochromia, increased $\mathrm{HbA}_{2}$, and unbalanced globin chain synthesis. Several procedures have been proposed for $\beta$-thalassemia carrier screening (Cao et al. 1998). The methodology most often used in the preliminary selection of individuals at risk of being carriers is the determination of the mean corpuscular volume (MCV) and mean corpuscular $\mathrm{Hb}$ concentration $(\mathrm{MCH})$ (Fig. 2). An alternative for this approach proposed for the South Asian population (especially for subjects living in rural areas) is the one-tube fragility test (OF) associated with the dichlorophenol indophenol (DCIP) dye test to detect the presence of $\mathrm{HbE}$, which is very common in this region and when interacting with $\beta$-thalassemia leads to $\beta$-thalassemia major or intermedia (Fucharoen et al. 2004). Those individuals resulting positive at this screening test are further investigated by quantitative determination of $\mathrm{HbA}_{2}$, which is the most important feature for identifying heterozygous $\beta$-thalassemia (Weatherall and Clegg 2001). However, both MCV-MCH determination and especially the one-tube fragility test, may miss those $\beta$ thalassemia heterozygotes who coinherited $\alpha$ thalassemia (Melis et al. 1983; Rosatelli et al. 1984). In carriers of $\beta^{0}$-thalassemia, the $\alpha$-thalassemia determinants giving rise to this effect are the deletion of two $\alpha$-globin genes or one of the nondeletion mutations affecting the major $\alpha_{2}$-globin gene. These carriers may be still easily identified because they have the typical increase of $\mathrm{HbA}_{2}$ levels. Another cause for normal or borderline $\mathrm{MCV}-\mathrm{MCH}$ values in carriers of $\beta$ thalassemia is a mild $\beta$-thalassemia mutation, including $\mathrm{HbE}, \mathrm{Hb}$ Knossos, and $\mathrm{Hb}$ Malay (Weatherall and Clegg 2001). A high frequency of both $\alpha$ - and $\beta$-thalassemia is common in many of the populations at risk such as those living in the Mediterranean area, and the Middle and Far East. In Sardinia, for instance, because of the high frequency of $\alpha$-thalassemia, $13.5 \%$ of $\beta$-thalassemia carriers have normalborderline $\mathrm{MCV}-\mathrm{MCH}$ values. The major 
The Prevention of Thalassemia

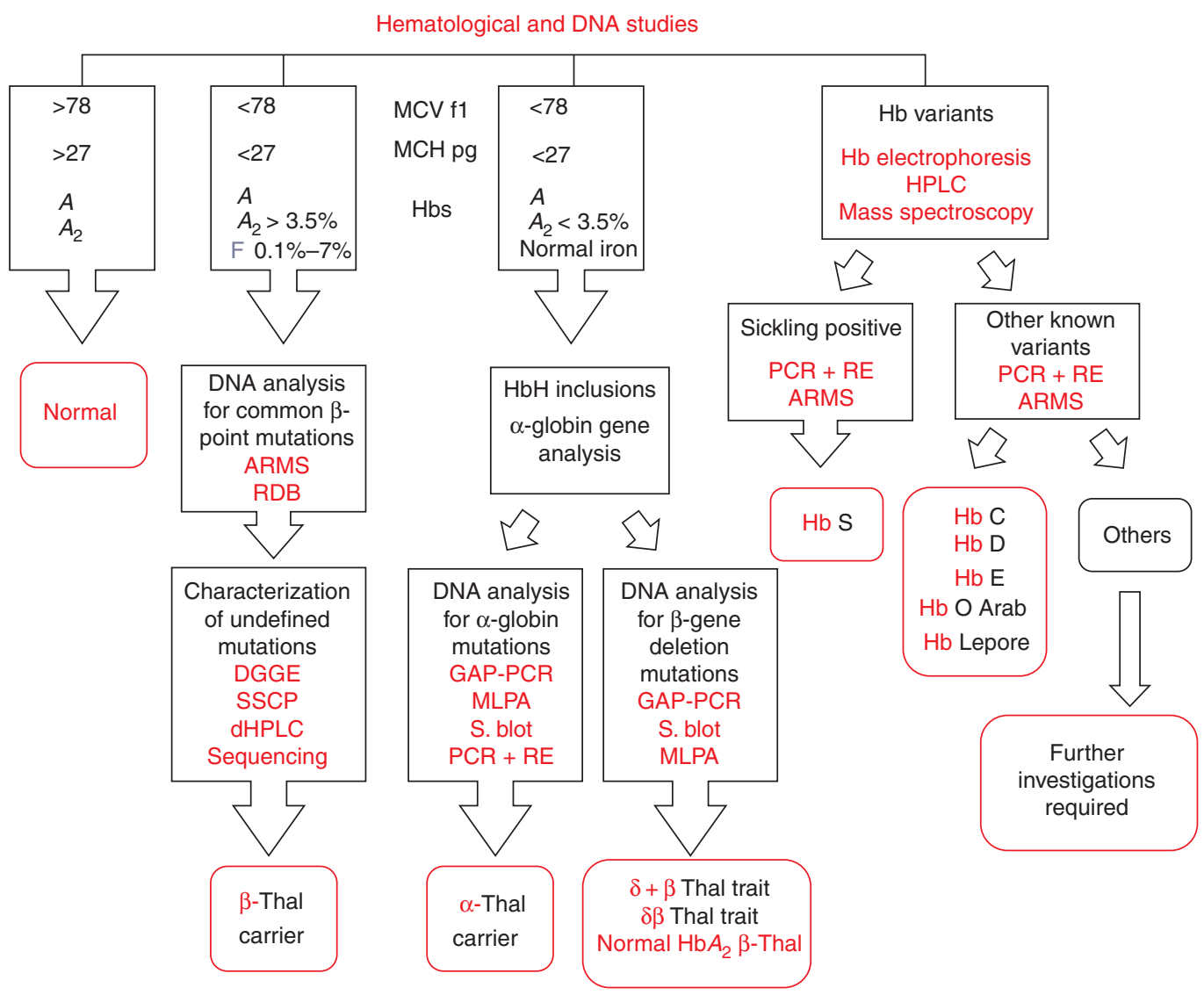

Figure 2. Flow chart for $\beta$-thalassemia carrier screening applied in Sardinia. Thal, thalassemia; S. blot, Southern blotting.

hematologic characteristic for identifying the $\beta$ thalassemia carrier state is the increase of $\mathrm{HbA}_{2}$ levels $(3.8 \%-6 \%$ in our laboratory). However, a variable but substantial number (in the different populations at risk) of $\beta$-thalassemia heterozygotes may have a normal level of $\mathrm{HbA}_{2}$ (normal $\mathrm{HbA}_{2} \beta$-thalassemia). The first mechanism determining this phenotype is the presence of heterozygosity for a $\beta$-thalassemia mutation associated with a significant residual output of $\beta$-globin chains from the affected locus (mild $\beta$-thalassemia), such as the common Mediterranean $\beta^{+}$-thalassemia IVS nt 6 mutations (HBB c. $92+6 \mathrm{~T} \rightarrow \mathrm{C}$ ) or some promoter mutation, i.e., the $-92 \mathrm{C} \rightarrow \mathrm{T}$ (HBB c. $142 \mathrm{C}$ $\rightarrow \mathrm{T}$ ). However, normal $\mathrm{HbA}_{2} \beta$-thalassemia may also result from coinheritance with $\beta$-thalassemia, of $\delta$-thalassemia mutations in cis or in trans, which determine a decrease in $\delta$-chain production, thereby resulting in normalization of $\mathrm{HbA}_{2}$ (normal $\mathrm{HbA}_{2} \beta$-thalassemia type 2) (Kattamis et al. 1979; Moi et al. 1988). Double heterozygotes for $\beta$ - and $\delta$-thalassemia may be diagnosed by family studies, globin chain synthesis analysis, and/or $\alpha-, \delta$-, and $\beta$-gene analysis. Many different mutations have been so far defined. $\delta$-Thalassemia is a relatively common genetic condition (Loudianos et al. 1992; Moi et al. 1992). The presence of a $\delta$-chain variant may also be associated with normal $\mathrm{HbA}_{2}$ levels (Waye et al. 2003; Phylipsen et al. 2010; So et al. 2011). This condition may be recognized from the presence of an additional band in the electrophoretic pattern or a peak on the chromatogram in the region where $\mathrm{HbA}_{2}$ also migrates. In $\beta$-thalassemia carriers, the sum of normal plus 
variant $\mathrm{HbA}_{2}$ is, however, increased. Normal $\mathrm{HbA}_{2} \beta$-thalassemia heterozygotes should be differentiated from $\alpha$-thalassemia carriers who show the same hematological features. The rare $\varepsilon \gamma \delta \beta$-, $\gamma \delta \beta$-, and $\delta \beta$-thalassemias are also characterized by microcytosis and normal $\mathrm{HbA}_{2}$ levels. $\delta \beta$-Thalassemia may be easily defined by a marked increase of $\mathrm{HbF}$. Associated iron deficiency may result in decreased levels of $\mathrm{HbA}_{2}$. This effect, however, is only observed in the presence of severe anemia (Galanello et al. 1981). Iron studies can easily exclude this association.

Finally, a critical problem in $\beta$-thalassemia carrier screening is the identification of silent $\beta$ thalassemia or the triple-quadruple $\alpha$-gene arrangement, which by interacting with typical $\beta$-thalassemia may result in the clinical features of mild or severe $\beta$-thalassemia (thalassemia intermedia or major) (Galanello et al. 1983; Thein et al. 1984; Kulozik et al. 1987; Ristaldi et al. 1990; Harteveld et al. 2008; Sollaino et al. 2009; Faa et al. 2010). Silent $\beta$-thalassemia (normal $\mathrm{HbA}_{2} \beta$-thalassemia type 1 ) shows normal hematological features and $\mathrm{HbA}_{2}$ level and may be identified solely by globin chain synthesis analysis or $\beta$-globin gene analysis (Kattamis et al. 1979; Gonzalez-Redondo et al. 1989; Galanello et al. 1994). The triple or quadruple $\alpha$ globin gene arrangement, which also displays the phenotype of normal $\mathrm{HbA}_{2} \beta$-thalassemia type 1 , may show a slight unbalance of $\alpha / \beta+\gamma$ globin chain synthesis but may also have a balanced synthesis (Harteveld et al. 2008; Faa et al. 2010). The presence of these atypical carriers is generally suspected in families that already had a child affected by mild $\beta$-thalassemia, despite having one apparently normal parent, the other being a typical $\beta$-thalassemia carrier.

The finding of individuals with borderline $\mathrm{HbA}_{2}$ (level between 3.3\% and 3.8\% in our laboratory) and normal MCV and $\mathrm{MCH}$ creates a relevant problem in the process of thalassemia carrier identification. Known determinants causing this phenotype are the triple $\alpha$-globin gene arrangement, some $\beta$-promoter mutation $(\mathrm{HBB}$ c. $151 \mathrm{C} \rightarrow \mathrm{T}$ ), and rare $\mathrm{HBB}$ or $\mathrm{HBD}$ gene variant (Table 1) (Galanello et al. 1983, 1994; Gasperini et al. 1993). Recently, we per-
Table 1. Causes of borderline HbA2 levels

Some promoter mutation of the $\beta$-globin gene

Some silent $\beta$-thalassemia

Some HBB or HBD variants

Triple or quadruple $\alpha$-globin arrangement

KLF1 mutations

formed in the Sardinian population molecular analysis of the KLF1 gene (which codes for a zincfinger transcriptional factor) in a large group of individuals with borderline $\mathrm{HbA}_{2}$. KLF1 is able to activate in the perinatal period the $\beta$ globin gene and at the same time the BCL11A gene (Borg et al. 2010; Zhou et al. 2010), which is capable in turn to suppress the $\gamma$-chain production (Borg et al. 2010; Zhou et al. 2010). KLF1 gene mutation has been associated with many different phenotypes including hereditary persistence of fetal hemoglobin (HPFH), congenital dyserythropoietic anemia, and the ( $\mathrm{Lu}$ ) blood group phenotype (Singleton et al. 2008; Arnaud et al. 2010; Borg et al. 2010; Satta et al. 2011).

In our study, we show that a consistent proportion of individuals (35\%) with borderline $\mathrm{HbA}_{2}$ have pathogenic mutation in KLF1, resulting in the activation of the $\mathrm{HbD}$ gene and thereby in increased $\mathrm{HbA}_{2}$ levels (Perseu et al. 2011). This finding may facilitate the carrier detection and counseling thereby contributing to the success of the program.

In our opinion, a carrier detection procedure should be designed to avoid missing any couple at risk. For this reason we have included in the first group of examination, in addition to determination of $\mathrm{MCV}-\mathrm{MCH}$, the quantitative evaluation of $\mathrm{HbA}_{2}$, which may be obtained by electrophoresis or by high-pressure liquid chromatography (HPLC). HPLC has the additional advantage to quantitate also $\mathrm{HbF}$ and to detect clinical relevant $\mathrm{Hb}$ variants including $\mathrm{Hb}$ Knossos (a mild $\beta$-thalassemia allele), HbS, $\mathrm{HbC}, \mathrm{HbD}$ Punjab, $\mathrm{HbO} \mathrm{Arab}$, and $\mathrm{HbE}$, all of which may interact with $\beta$-thalassemia heterozygosity leading to thalassemia major or intermedia or sickle cell $\beta$-thalassemia. By this approach only silent $\beta$-thalassemia or the triple or quadruple $\alpha$-globin gene arrangement may escape detection. 
The critical issue in the screening process is the differential diagnosis of individuals with the phenotype of normal $\mathrm{HbA}_{2} \beta$-thalassemia type 2 (low MCV, low MCH, normal, or borderline $\mathrm{HbA}_{2}$ ), which may result from iron deficiency, $\alpha$-thalassemia, $\gamma \delta \beta$-thalassemia, double heterozygosity for $\beta$ - and $\delta$-thalassemia or mild $\beta$-thalassemia. After exclusion of iron deficiency by erythrocyte $\mathrm{ZnPP}$ and transferrin saturation determination, we differentiate the different thalassemia genotypes by $\alpha-/ \beta$-globin chain synthesis or $\alpha-, \delta$-, and $\beta$-gene analysis.

A hematological phenotype characterized by low $\mathrm{MCV}$ and $\mathrm{MCH}$, normal or reduced $\mathrm{HbA}_{2}$, and high $\mathrm{HbF}$ levels indicate the presence of $\delta \beta$-thalassemia. $\delta \beta$-Thalassemia may be confused with $\mathrm{HPFH}$. The differentiation is based on globin gene synthesis analysis or $\beta$-gene cluster studies; in addition, HPFH is characterized by lack of microcytosis and hypochromia.

\section{MOLECULAR DIAGNOSIS}

Molecular diagnosis of $\alpha$-, $\beta$-, and $\delta$-thalassemia when necessary may be performed by one of the PCR-based available procedures. $\beta$-Thalassemias display a marked heterogeneity at the molecular level. So far, $>200$ different mutations have been described. A complete updated list is available at the Globin Gene Server Web site-http://globin.cse.psu.edu. The large majority of these mutations are point mutation or the addition or deletion of one or a few nucleotides causing a frameshift. More rarely, $\beta$-thalassemias are produced by globin gene deletion. Despite this heterogeneity a limited number of molecular defects are present in each population at risk. This information may be useful for designing the appropriate primers or probes for each at-risk population (Fig. 3). Nowadays, known mutations are detected by a PCR-based procedure among which the most commonly used are commercially available RDB (reverse oligonucleotide hybridization) analysis (Saiki et al. 1989) and allele-specific amplification (amplification refractory mutation system [ARMS]) (Newton et al. 1989). Both methods, especially the RDB, can screen in one step up to 20-30 different mutations. Methodologies cur- rently used for identification of unknown mutations by scanning the entire gene were denaturing gradient gel electrophoresis (DDGE) (Myers et al. 1985; Cai and Kan 1990; Rosatelli et al. 1992), denaturing high-pressure liquid chromatography (dHPLC) (Sanger et al. 1977), and single-strand conformation polymorphism (SSCP) analysis (Orita et al. 1989). When mutation is not detected by these procedures, polyacrylamide gel electrophoresis of PCR-amplified product (gapPCR) may lead to the detection of a small deletion of the $\beta$-globin gene, which may be suspected by finding unusually high $\mathrm{HbA}_{2}$. The presence of rare large deletions, including deletion of LCR, is finally investigated by multiple ligation-dependent probe amplification (MLPA). These methods are now usually replaced by DNA sequence analysis.

Detection of the most frequent mutations/ deletions of the $\alpha$-globin gene, as for the $\beta$-globin gene detection, is also available using the PCR-RDB-based kits. Known deletions may be detected by PCR-based methods using primers flanking the deletion breakpoint. Primer panels targeted to the most common deletion found in the area of the geographic origin of the proband can be used (Galanello et al. 1998; Chong et al. 2000; Old et al. 2001). MLPA (Harteveld et al. 2005) or quantitative real-time PCR assay may also be used to detect less common mutations or novel deletion (Fallah et al. 2010). $\alpha$-Thalassemia mental retardation 16 (ATR16), a contiguous gene deletion, may also be detected by MLPA or array comparative genome hybridization (CGH) (Gibson et al. 2008).

\section{PREDICTION OF A MILD PHENOTYPE}

The severity of homozygous $\beta$-thalassemia depends on the extent of the imbalance between $\alpha$-globin and non- $\alpha$-globin (including $\beta$ - and $\gamma$-chains) chains. Any conditions able to reduce this unbalance results in a mild clinical phenotype referred to as thalassemia intermedia. The first molecular mechanism is related to severity of the $\beta$-thalassemia mutation present in each case (Higgs et al. 2011). Mild $\beta^{+}$-thalassemia (which also includes $\mathrm{HbE}$ ) and silent mutations are associated with adequate residual output of 


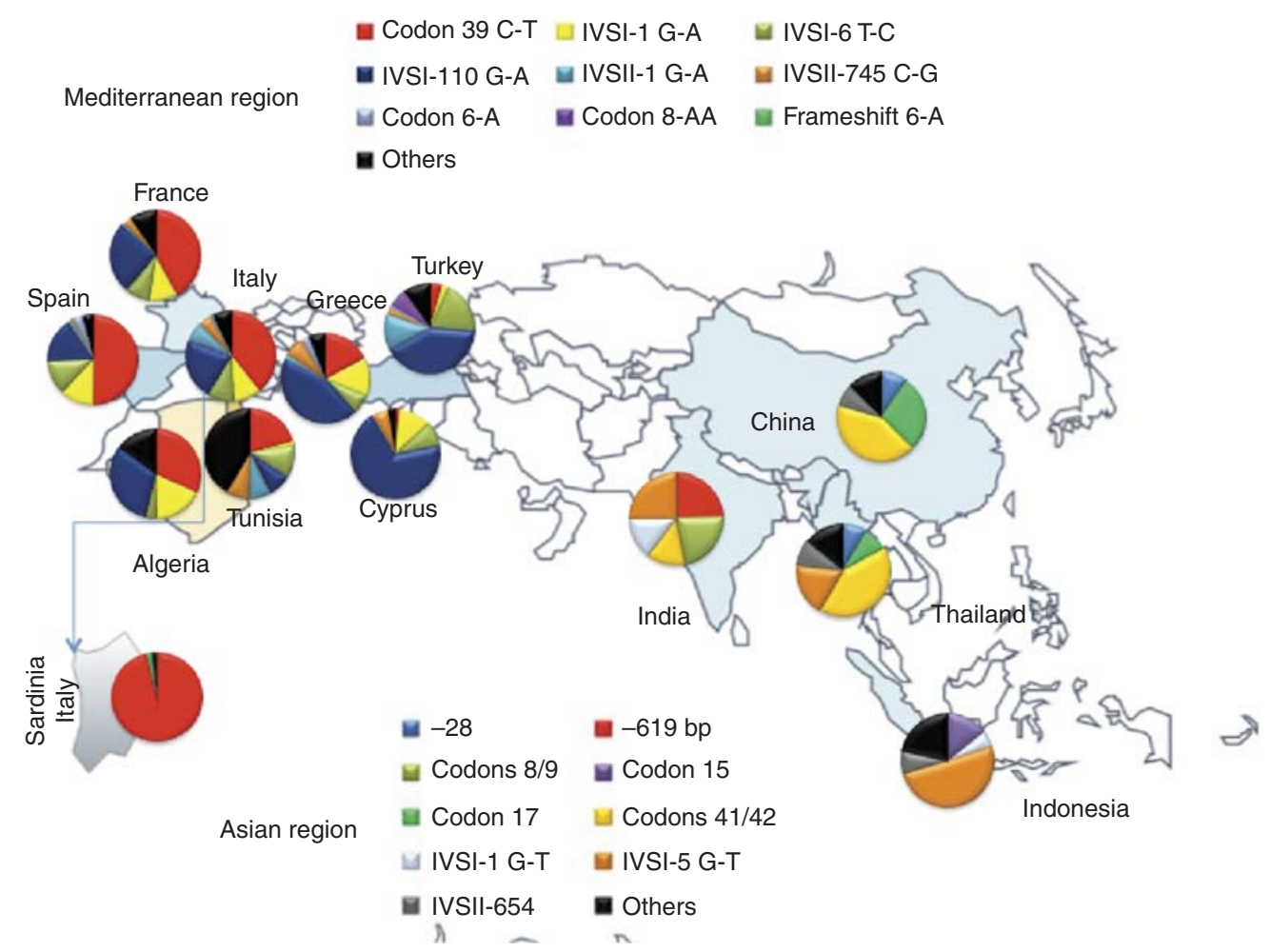

Figure 3. Population distribution of common $\beta$-thalassemia mutations.

the $\beta$-globin gene from the affected $\beta$-globin locus and thereby usually result in attenuated phenotypes in the homozygosity or compound heterozygous state. In contrast, compound heterozygotes for a mild $\beta^{+}$-thalassemia or silent mutation and a severe mutation produce a variable phenotype ranging from thalassemia major to thalassemia intermedia. Therefore, the presence of this genotype does not consent to consistently predict a mild phenotype.

The second recognized mechanism for producing a mild phenotype is the coinheritance with homozygous $\beta$-thalassemia of $\alpha$-thalassemia, which, by reducing the output of $\alpha$ chains, decreases the $\alpha-/$ non- $\alpha$-chain imbalance (Wainscoat et al. 1983; Galanello et al. 1989). A consistent ameliorating effect is observed when the $\alpha$-thalassemia determinant consists of the deletion of two $\alpha$-globin structural genes or of an inactivating mutation of the major $\alpha 2$-globin gene (Wainscoat et al. 1983; Galanello et al. 1989; Thein 2008). However, be- cause this effect is not constantly seen, the coinheritance of $\alpha$-thalassemia cannot be recommended to predict the phenotype.

Finally, the coinheritance of genetic determinants able to sustain a continuous high production of $\gamma$-globin chains in adult life, may ameliorate homozygous $\beta$-thalassemia by reducing the $\alpha-/$ non- $\alpha$-chain imbalance.

Genetic conditions associated with increased $\mathrm{HbF}$ in adult life and therefore able to ameriolate the phenotype of $\beta$-thalassemia are listed in Table 2. Recent studies using genomewide association studies (GWAS) have identified two quantitative trait loci (QTL) (BCL11A on chromosome 2p16 and HBS1L-MYB intergenic region most likely involving MYB on chromosome 6q23) that account for $\sim 20 \%-30 \%$ of the common variation in $\mathrm{HbF}$ levels in healthy adults as well as in persons with $\beta$-thalassemia and sickle cell disease (Uda et al. 2008; Thein and Menzel 2009). In Sardinians, the alleles of BCL11A associated with high $\mathrm{HbF}$ were found 
Table 2. Genetic conditions with increased $\mathrm{HbF}$ in adult life

\begin{tabular}{l} 
Linked to the $\boldsymbol{\beta}$-cluster \\
HPFH \\
$\delta \beta$-Thalassemias \\
Deletions of the $5^{\prime}$ region of the HBB promoter \\
Point mutation of the G $\gamma(\mathrm{HBG})(-158 \mathrm{C} \rightarrow \mathrm{T}$ G $\gamma$ \\
mutation) \\
Point mutation of the A $\gamma$ (HBG1) $(-196 \mathrm{G} \rightarrow \mathrm{TA} \gamma$ \\
$\quad$ mutation) \\
QTL 11q (HS3 locus); locus downstream from HBG1 \\
$\quad$ (Galarneau et al. 2010) \\
Unlinked to the $\boldsymbol{\beta}$-cluster \\
BCL11A \\
HBSA1L-MYB region \\
Others (chromosome 13) \\
\hline HPFH, hereditary persistence of fetal hemoglobin.
\end{tabular}

more frequently in patients with thalassemia intermedia as compared to those affected by thalassemia major, indicating that those loci exert, by increasing $\mathrm{HbF}$, an ameliorating effect on homozygous $\beta^{0}$-thalassemia (Uda et al. 2008; Galanello et al. 2009). These results were confirmed in patients with sickle cell anemia from the United States and Brazil (Lettre et al. 2008) and $\beta$-thalassemias in France (Badens et al. 2011). The two loci, in addition to coinherited $\alpha$-thalassemia, act in additive fashion, accounting for $\sim 75 \%$ of the variation in clinical severity in Sardinian $\beta^{0}$-thalassemias (Galanello et al. 2009). Genotyping at these loci in prospective parents may have a practical utility as a prognostic indicator for the severity of $\beta$-thalassemia and sickle cell anemia, thereby improving the genetic counseling. It is likely that many other HbF-associated QTL exist such as that recently defined on chromosome 13 (Sankaran and Nathan 2010).

\section{GENETIC COUNSELING}

Limited information is available in the literature concerning the approach for counseling by thalassemia centers. A working party several years ago discussed the problem and presented some recommendations (WHO 1994). I would like therefore to concentrate on our own experience in Sardinia. According to international rules, counseling has been performed in a nondirective way and was based on a private interview. A pediatrician trained in genetics is responsible for counseling the couples identified to be at risk, whereas a trained nurse deals with individuals not yet married. The information provided is aimed at giving an informed basis on which to make a decision about reproduction. The discussion includes various options available such as birth control, mate selection, adoption, fetal testing including prenatal diagnosis and preimplantation diagnosis, or artificial insemination by normal donors as well as the details of the natural history of the disease. When the genotypes indicate the possible development of a mild phenotype, we also prudently discuss this point, emphasizing that the development of this phenotype should be considered a probability and not a certainty.

I strongly believe that the counseling according to international guidelines should be based on truth, complete honesty, and frankness. Other experts, before the recent discovery on $\mathrm{HbF}$ QTL, were of the opinion that this phenotype prediction should not be discussed (Weatherall and Clegg 2001).

In cases with a previous nonaffected child, we propose HLA typing on fetal DNA, to check whether the sibling could be HLA identical and therefore a suitable bone marrow donor (Orofino et al. 2003). This information could be useful for deciding on noninterruption of the pregnancy in the case of an affected fetus. In Sardinia, as well in other Mediterranean countries ( $\mathrm{Cy}$ prus, Continental Italy, and Greece) and from recently published papers also in Muslim countries such as Iran, the option of prenatal diagnosis is followed by the majority of the couples counseled. Last, we inform the counselee about the risk for their relatives and recommend informing them about the result. This inductive screening is a very efficient way to multiply the efficacy of the screening as reported also in Pakistani populations (Ahmed et al. 2002).

\section{PRENATAL DIAGNOSIS}

The possibility of prenatal diagnosis of inherited hemoglobinopathies was first suggested by the 
discovery that $\beta$-globin chain synthesis in cord blood of $\beta$-thalassemia heterozygotes was significantly lower than normal (Kan and Nathan 1968) and that adult hemoglobin synthesis could be detected in fetuses at midtrimester (Hollenberg et al. 1971). Later on, the $\beta^{S}$-chain was detected in the blood of fetuses (Kan et al. 1972). Fetal blood sampling by fetoscopy or placentocentesis was then set up (Hobbins and Mahoney 1974; Kan et al. 1974) and paved the way to introduce prenatal diagnosis by globin chain synthesis on fetal blood (Kan et al. 1975). These techniques were used for 5 years. The first molecular diagnosis was performed for the diagnosis of $\alpha$-thalassemia by the technique of molecular hybridization (Kan et al. 1976). For a short period diagnosis of $\beta$-thalassemia by DNA analysis was obtained indirectly by analysis of DNA polymorphisms linked to the $\beta$-globin gene (Kan et al. 1980) or directly by mutation-specific oligonucleotide hybridization on electrophoretically separated DNA fragments (Pirastu et al. 1983).

Nowadays, thalassemias are detected directly by the analysis of amplified DNA from fetal trophoblast or amniotic fluid cells. Fetal DNA is obtained transabdominally by chorionic villus sampling. This technique has been chosen by many centers because of the advantage of being used within the first trimester and because it is associated with a low risk $(\sim 1 \%)$ of fetal mortality. Fetal DNA is analyzed with one of the methods described for the detection of known mutations in the process of carrier identification. Prenatal diagnosis by DNA analysis is today available in many at-risk populations, including those from Hong Kong, Taiwan, China, and India, in addition to those from the Mediterranean area, Northern Europe, and Northern and South America (Eleftheiou and Angastionitis 2011).

Misdiagnosis may occur for several reasons: i.e., failure to amplify the DNA fragment, mispaternity, maternal contamination, and sample exchange. To limit the possibility of misdiagnosis, we analyze the fetal DNA with two different techniques (ARMS and RDB) and carry out DNA polymorphism analysis to detect maternal contamination and mispaternity. The PCRbased technique of prenatal diagnosis turned out to be very reliable. In our center we had no misdiagnoses in $\sim 6000$ cases performed so far. Similar results have been reported by others (Angastiniotis et al. 1995).

Fetal anemia may be diagnosed at mid-trimester gestation by quantitation of middle cerebral artery peak systolic velocity. This technique has been applied successfully to prenatal identification of Hb Bart's fetal hydrops syndrome (Lam and Tang 2002; Srisupundit et al. 2009). However, false negatives have been recorded using this technology. Mutation analysis of $\alpha$-globin genes may be used to detect deletion and nondeletion $\alpha$-thalassemia.

\section{PREIMPLANTATION AND PRECONCEPTIONAL GENETIC DIAGNOSIS}

The progress in molecular genetics to analyze the genotype of a single cell, together with advances in assisted reproduction techniques, has paved the way for developing preimplantation and preconceptional diagnosis (Handyside et al. 1990; Monk and Holding 1990). These techniques are nowadays widely available, including countries where $\beta$-thalassemia is prevalent such as Cyprus (Kulievet al.2011), Continental Greece (Zachaki et al. 2011), and China (Jiao et al. 2003; Xu et al. 2009). Preimplantation genetic diagnosis is performed either by biopsy of one to two blastomeres in eight-cell embryos after in vitro fertilization (by intracytoplasmatic sperm injection) or by biopsy of trophectoderm cells from blastocyst (Kuliev et al. 1998; Kokkali et al. 2007).

Preconceptional diagnosis is based on the analysis of the first polar body of unfertilized eggs followed by analysis of the second polar bodies after fertilization, which is performed to avoid misdiagnosis resulting from recombination during the first meiosis (Verlinsky et al. 1990). Diagnosis was obtained by multiple nested PCR analysis to detect the mutations as well as polymorphic alleles at the $\beta$-globin cluster (Kuliev et al. 2011; Zachaki et al. 2011). HLA typing of the embryo to select a nonaffected fetus HLA compatible with a previous affected sibling was recently proposed (Kuliev et al. 2011).

The biopsy of blastomeres from an eight-cell embryo is nowadays the most frequently used 
The Prevention of Thalassemia

procedure worldwide. This approach minimizes the risk of misdiagnosis that could result from PCR failure, contamination, and allelic dropout that is a definite risk in single-cell analysis. In a large series, misdiagnosis was rare and the pregnancy rate high $(32 \%)$ (Kuliev et al. 2011). The motivations for couples following counseling to opt for preimplantation genetic diagnosis (PGD) are problems of infertility, an unsuccessful reproductive history owing to repeated terminations of affected fetuses, moral or religious attitude against pregnancy termination, and the desire to have a nonaffected fetus HLA compatible with a previously homozygously affected sibling for future bone marrow transplantation. Genetic counseling for couples considering PGD should include a discussion on the risk associated with in vitro fertilization and embryo biopsy, the risk of failure and/or misdiagnosis, and the need of subsequent prenatal diagnosis for confirming the results. At present, however, the technical demand for these procedures, the difficulty in organizing the service, and the high cost preclude its use for monitoring worldwide pregnancies at risk.

\section{PRENATAL DIAGNOSIS BY NONINVASIVE PROCEDURES}

Several attempts have been made to make fetal diagnosis by analysis of fetal cells in maternal circulation (Simpson and Elias 1993; Adinolfi 1995; Cheung et al. 1996; Bianchi et al. 1997). However, the complexity of the cell isolation process and the lack of reproducibility preclude the use of this approach in clinical practice. Likewise, many studies have been performed to make the diagnosis of $\beta$-thalassemia or $\alpha$ thalassemia by analysis of fetal DNA in maternal plasma (Lo et al. 1997; Lun et al. 2008). These noninvasive diagnostic methods, while gradually being introduced for chromosomal defects, require more refinement for globin and other single gene disorders. It should, however, be mentioned that a diagnosis of $\beta$-thalassemia was recently realized by the Lo group with next-generation sequencing (paired and massively, parallel sequencing) of the fetal and maternal DNA genomes present in maternal plasma (Lo et al. 2010).

\section{OUTCOME OF THE PROGRAMS}

The primary effect of the programs for preventing $\beta$-thalassemia in the Mediterranean populations has been the acquisition by the couples at risk of the appropriate knowledge to make informed decisions on the reproductive options available to them. This awareness of the genetic risk and methods of prevention led to a marked acceptance of fetal testing leading to a consistent decline in the birth rate of thalassemia major in

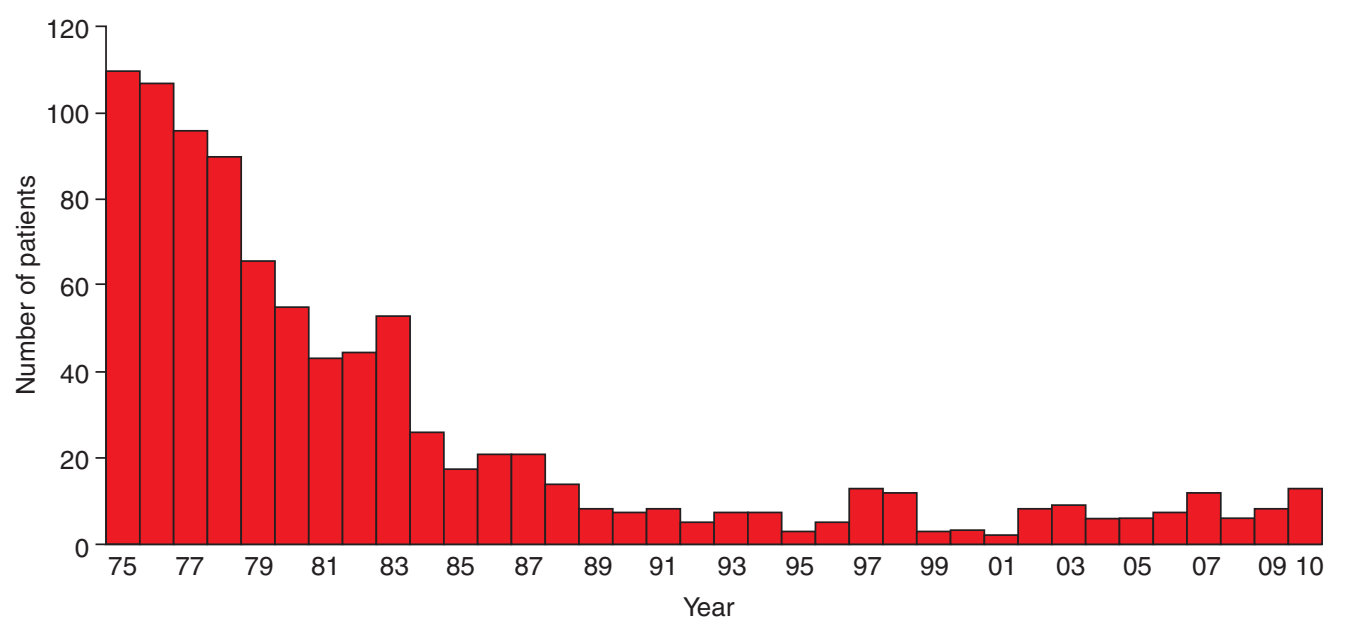

Figure 4. Decline of birth rate of thalassemia major in Sardinia. 
these populations. In Sardinia, for instance, the number of thalassemia major children born per year predicted on the basis of the carrier rate, assuming a random mating, shows a reduction from 1:250 live births to 1:1660 in 2009 with an effective prevention of $85 \%$ of the cases (Fig. 4). Similar results have been reported in Cyprus (Angastiniotis and Modell 1998). The dissolution of the marriage or the decision not to have children is less commonly followed, except in Muslim countries, where the breakup of marriages seems to occur more often.

Despite well-organized prevention programs, reasons for the birth of affected children are negative attitudes against fetal testing following counseling and decision to continue the pregnancy despite the documented presence of an affected fetus for religious or ethical reasons. Less common motivations are misinformation, lack of information, mispaternity, and mistakes in fetal testing. Although research on this topic is not available, it seems that the programs had no adverse effects.

\section{FUTURE PROSPECTIVES}

Education on thalassemias may be implemented by using informatic channels. The continuous reduction in the cost of DNA analysis may lead to its application as the initial step in the screening process. Using microchip technology targeted to detect all the known $\alpha$ - and $\beta$-thalassemias as well as DNA polymorphisms is useful to predict the phenotype, thereby making it possible to skip the preliminary hematological analysis.

Technical advances in the methodologies of fetal DNA or fetal cells analysis in maternal plasma may allow in the future the introduction of this important noninvasive technique in clinical practice.

Finally, the most important challenge for the future is the organization of national preventive programs in populations in which thalassemias are prevalent such as the Middle East, the Indian subcontinent, and the Far East, where several factors previously discussed preclude at the present time the realization of such programs.

\section{REFERENCES}

Adinolfi M. 1995. Non- or minimally invasive prenatal diagnostic tests on maternal blood samples or transcervical cells. Prenat Diagn 15: 889-896.

Ahmed S, Saleem M, Modell B, Petrou M. 2002. Screening extended families for genetic hemoglobin disorders in Pakistan. N Engl J Med 347: 1162-1168.

Alwan A, Modell B. 2003. Recommendations for introducing genetics services in developing countries. Nat Rev Genet 4: 61-68.

Amato A, Grisanti P, Lerone M, Ponzini D, Di Biagio P, Cappabianca MP, Giordano PC. 2009. Prevention strategies for severe hemoglobinopathies in endemic and nonendemic immigration countries: The Latium example. Prenat Diagn 29: 1171-1174.

Angastiniotis MA, Hadjiminas MG. 1981. Prevention of thalassaemia in Cyprus. Lancet 1: 369-371.

Angastiniotis M, Modell B. 1998. Global epidemiology of hemoglobin disorders. Ann NY Acad Sci 850: 251-269.

Angastiniotis M, Modell B, Englezos P, Boulyjenkov V. 1995. Prevention and control of haemoglobinopathies. Bull World Health Organ 73: 375-386.

Arnaud L, Saison C, Helias V, Lucien N, Steschenko D, Giarratana MC, Prehu C, Foliguet B, Montout L, de Brevern AG, et al. 2010. A dominant mutation in the gene encoding the erythroid transcription factor KLF1 causes a congenital dyserythropoietic anemia. Am J Hum Genet 87: 721-727.

Badens C, Joly P, Agouti I, Thuret I, Gonnet K, Fattoum S, Francina A, Simeoni MC, Loundou A, Pissard S. 2011. Variants in genetic modifiers of $\beta$-thalassemia can help to predict the major or intermedia type of the disease. Haematologica 96: 1712-1714.

Bianchi DW, Williams JM, Sullivan LM, Hanson FW, Klinger KW, Shuber AP. 1997. PCR quantitation of fetal cells in maternal blood in normal and aneuploid pregnancies. Am J Hum Genet 61: 822-829.

Borg J, Papadopoulos P, Georgitsi M, Gutierrez L, Grech G, Fanis P, Phylactides M, Verkerk AJ, van der Spek PJ, Scerri CA, et al. 2010. Haploinsufficiency for the erythroid transcription factor KLF1 causes hereditary persistence of fetal hemoglobin. Nat Genet 42: 801-805.

Cai SP, Kan YW. 1990. Identification of the multiple $\beta$-thalassemia mutations by denaturing gradient gel electrophoresis. J Clin Invest 85: 550-553.

Canatan D, Kose MR, Ustundag M, Haznedaroglu D, Ozbas S. 2006. Hemoglobinopathy control program in Turkey. Community Genet 9: 124-126.

Cao A, Rosatelli MC, Galanello R. 1996. Control of $\beta$-thalassaemia by carrier screening, genetic counselling and prenatal diagnosis: The Sardinian experience. Ciba Found Symp 197: 137-151; discussion 151-135.

Cao A, Galanello R, Rosatelli MC. 1998. Prenatal diagnosis and screening of the haemoglobinopathies. Baillieres Clin Haematol 11: 215-238.

Cao A, Congiu R, Sollaino MC, Desogus MF, Demartis FR, Loi D, Cau M, Galanello R. 2008. Thalassaemia and glucose-6-phosphate dehydrogenase screening in 13- to 14year-old students of the Sardinian population: Preliminary findings. Community Genet 11: 121-128. 
Chern JP, Lin KH, Su YN, Lu MY, Jou ST, Lin DT, Wang SC, Lin KS. 2006. Impact of a national $\beta$-thalassemia carrier screening program on the birth rate of thalassemia major. Pediatr Blood Cancer 46: 72-76.

Cheung MC, Goldberg JD, Kan YW. 1996. Prenatal diagnosis of sickle cell anaemia and thalassaemia by analysis of fetal cells in maternal blood. Nat Genet 14: 264-268.

Chong SS, Boehm CD, Higgs DR, Cutting GR. 2000. Singletube multiplex-PCR screen for common deletional determinants of $\alpha$-thalassemia. Blood 95: 360-362.

Chui DH. 2005. $\alpha$-Thalassemia: $\mathrm{Hb} \mathrm{H}$ disease and $\mathrm{Hb}$ Barts hydrops fetalis. Ann NY Acad Sci 1054: 25-32.

Faa V, Masala M, Cao A, Rosatelli MC. 2010. $\alpha$ Globin gene duplications in $\beta$ thalassemia patients with intact $\beta$ globin gene. Blood Cells Mol Dis 44: 156-158.

Fallah MS, Mahdian R, Aleyasin SA, Jamali S, HayatNosaeid M, Karimipour M, Raeisi M, Zeinali S. 2010. Development of a quantitative real-time PCR assay for detection of unknown $\alpha$-globin gene deletions. Blood Cells $\mathrm{Mol}$ Dis 45: 58-64.

Fucharoen G, Sanchaisuriya K, Sae-ung N, Dangwibul S, Fucharoen S. 2004. A simplified screening strategy for thalassaemia and haemoglobin $\mathrm{E}$ in rural communities in south-east Asia. Bull World Health Organ 82: 364-372.

Galanello R, Ruggeri R, Addis M, Paglietti E, Cao A. 1981. Hemoglobin A2 in iron deficient $\beta$-thalassemia heterozygotes. Hemoglobin 5: 613-618.

Galanello R, Ruggeri R, Paglietti E, Addis M, Melis MA, Cao A. 1983. A family with segregating triplicated $\alpha$ globin loci and $\beta$ thalassemia. Blood 62: 1035-1040.

Galanello R, Dessi E, Melis MA, Addis M, Sanna MA, Rosatelli C, Argiolu F, Giagu N, Turco MP, Cacace E, et al. 1989. Molecular analysis of $\beta^{0}$-thalassemia intermedia in Sardinia. Blood 74: 823-827.

Galanello R, Barella S, Ideo A, Gasperini D, Rosatelli C, Paderi L, Paglietti E, Sollaino C, Perseu L, Loi D, et al. 1994. Genotype of subjects with borderline hemoglobin A2 levels: Implication for $\beta$-thalassemia carrier screening. Am J Hematol 46: 79-81.

Galanello R, Sollaino C, Paglietti E, Barella S, Perra C, Doneddu I, Pirroni MG, Maccioni L, Cao A. 1998. $\alpha$ Thalassemia carrier identification by DNA analysis in the screening for thalassemia. Am J Hematol 59: 273-278.

Galanello R, Sanna S, Perseu L, Sollaino MC, Satta S, Lai ME, Barella S, Uda M, Usala G, Abecasis GR, et al. 2009. Amelioration of Sardinian $\beta^{0}$ thalassemia by genetic modifiers. Blood 114: 3935-3937.

Galarneau G, Palmer CD, Sankaran VG, Orkin SH, Hirschhorn JN, Lettre G. 2010. Fine-mapping at three loci known to affect fetal hemoglobin levels explains additional genetic variation. Nat Genet 42: 1049-1051.

Gasperini D, Cao A, Paderi L, Barella S, Paglietti E, Perseu L, Loi D, Galanello R. 1993. Normal individuals with high $\mathrm{Hb}$ A2 levels. Br J Haematol 84: 166-168.

Gibson WT, Harvard C, Qiao Y, Somerville MJ, Lewis ME, Rajcan-Separovic E. 2008. Phenotype-genotype characterization of $\alpha$-thalassemia mental retardation syndrome due to isolated monosomy of 16p13.3. Am J Med Genet A 146A: $225-232$.

Gonzalez-Redondo JM, Stoming TA, Kutlar A, Kutlar F, Lanclos KD, Howard EF, Fei YJ, Aksoy M, Altay C,
Gurgey A, et al. 1989. A C $\rightarrow$ T substitution at nt -101 in a conserved DNA sequence of the promotor region of the $\beta$-globin gene is associated with "silent" $\beta$-thalassemia. Blood 73: 1705-1711.

Handyside AH, Kontogianni EH, Hardy K, Winston RM. 1990. Pregnancies from biopsied human preimplantation embryos sexed by Y-specific DNA amplification. Nature 344: 768-770.

Harteveld CL, Voskamp A, Phylipsen M, Akkermans N, den Dunnen JT, White SJ, Giordano PC. 2005. Nine unknown rearrangements in $16 \mathrm{p} 13.3$ and $11 \mathrm{p} 15.4$ causing $\alpha$ - and $\beta$-thalassaemia characterised by high resolution multiplex ligation-dependent probe amplification. J Med Genet 42: 922-931.

Harteveld CL, Refaldi C, Cassinerio E, Cappellini MD, Giordano PC. 2008. Segmental duplications involving the $\alpha$-globin gene cluster are causing $\beta$-thalassemia intermedia phenotypes in $\beta$-thalassemia heterozygous patients. Blood Cells Mol Dis 40: 312-316.

Higgs DR, Engel JD, Stamatoyannopoulos G. 2011. Thalassaemia. Lancet 379: 373-383.

Hobbins JC, Mahoney MJ. 1974. In utero diagnosis of hemoglobinopathies. Technic for obtaining fetal blood. N Engl J Med 290: 1065-1067.

Hollenberg MD, Kaback MM, Kazazian HH Jr, 1971. Adult hemoglobin synthesis by reticulocytes from the human fetus at midtrimester. Science 174: 698-702.

Inati A, Zeineh N, Isma'eel H, Koussa S, Gharzuddine W, Taher A. 2006. $\beta$-thalassemia: The Lebanese experience. Clin Lab Haematol 28: 217-227.

Jiao ZX, Zhuang GL, Zhou CQ, Shu YM, Li J, Liang XY, Zhang MF, Deng MF. 2003. Successful preimplantation genetic diagnosis for $\beta$-thalassemia using primer extension preamplification. Zhonghua Fu Chan Ke Za Zhi 38: $143-146$.

Kalokairinou EM. 2007. The experience of $\beta$-thalassaemia and its prevention in Cyprus. Med Law 26: 291-307.

Kalokairinou EM. 2008. The experience of $\beta$-thalassaemia and its prevention in Cyprus. Med Law 27: 825-841.

Kan YW, Nathan DG. 1968. $\beta$ Thalassemia trait: Detection at birth. Science 161: 589-590.

Kan YW, Dozy AM, Alter BP, Frigoletto FD, Nathan DG. 1972. Detection of the sickle gene in the human fetus. Potential for intrauterine diagnosis of sickle-cell anemia. N Engl J Med 287: 1-5.

Kan YW, Valenti C, Carnazza V, Guidotti R, Rieder RF. 1974. Fetal blood-sampling in utero. Lancet 1: 79-80.

Kan YW, Golbus MS, Klein P, Dozy AM. 1975. Successful application of prenatal diagnosis in a pregnancy at risk for homozygous $\beta$-thalassemia. $N$ Engl J Med 292: 1096-1099.

Kan YW, Golbus MS, Dozy AM. 1976. Prenatal diagnosis of $\alpha$-thalassemia. Clinical application of molecular hybridization. N Engl J Med 295: 1165-1167.

Kan YW, Lee KY, Furbetta M, Angius A, Cao A. 1980. Polymorphism of DNA sequence in the $\beta$-globin gene region. Application to prenatal diagnosis of $\beta^{0}$ thalassemia in Sardinia. N Engl J Med 302: 185-188.

Kattamis C, Metaxotou-Mavromati A, Wood WG, Nash JR, Weatherall DJ. 1979. The heterogeneity of normal Hb A2$\beta$ thalassaemia in Greece. Br J Haematol 42: 109-123. 
Kokkali G, Traeger-Synodinos J, Vrettou C, Stavrou D, Jones GM, Cram DS, Makrakis E, Trounson AO, Kanavakis E, Pantos K. 2007. Blastocyst biopsy versus cleavage stage biopsy and blastocyst transfer for preimplantation genetic diagnosis of $\beta$-thalassaemia: A pilot study. Hum Reprod 22: 1443-1449.

Kolnagou A, Kontoghiorghes GJ. 2009. Advances in the prevention and treatment are changing thalassemia from a fatal to a chronic disease. Experience from a $\mathrm{Cy}$ prus model and its use as a paradigm for future applications. Hemoglobin 33: 287-295.

Kuliev A, Rechitsky S, Verlinsky O, Ivakhnenko V, Evsikov S, Wolf G, Angastiniotis M, Georghiou D, Kukharenko V Strom C, et al. 1998. Preimplantation diagnosis of thalassemias. J Assist Reprod Genet 15: 219-225.

Kuliev A, Pakhalchuk T, Verlinsky O, Rechitsky S. 2011 Preimplantation genetic diagnosis for hemoglobinopathies. Hemoglobin 31: 273-277.

Kulozik AE, Thein SL, Wainscoat JS, Gale R, Kay LA, Wood JK, Weatherall DJ, Huehns ER. 1987. Thalassaemia intermedia: Interaction of the triple $\alpha$-globin gene arrangement and heterozygous $\beta$-thalassaemia. $\mathrm{Br} \mathrm{J} \mathrm{Hae-}$ matol 66: 109-112.

Lam YH, Tang MH. 2002. Middle cerebral artery Doppler study in fetuses with homozygous $\alpha$-thalassaemia-1 at 12-13 weeks of gestation. Prenat Diagn 22: 56-58.

Lettre G, Sankaran VG, Bezerra MA, Araujo AS, Uda M, Sanna S, Cao A, Schlessinger D, Costa FF, Hirschhorn JN, et al. 2008. DNA polymorphisms at the BCL11A, HBS1LMYB, and $\beta$-globin loci associate with fetal hemoglobin levels and pain crises in sickle cell disease. Proc Natl Acad Sci 105: 11869-11874.

Li DZ. 2009. Premarital screening for thalassemia in mainland China. Prenat Diagn 29: 637-638.

Lo YM, Corbetta N, Chamberlain PF, Rai V, Sargent IL, Redman CW, Wainscoat JS. 1997. Presence of fetal DNA in maternal plasma and serum. Lancet 350: $485-$ 487.

Lo YM, Chan KC, Sun H, Chen EZ, Jiang P, Lun FM, Zheng YW, Leung TY, Lau TK, Cantor CR, et al. 2010. Maternal plasma DNA sequencing reveals the genomewide genetic and mutational profile of the fetus. Sci Transl Med 2: 61ra91.

Loudianos G, Murru S, Ristaldi MS, Cossu P, Pilia G, Porcu S, Sciarratta GV, Parodi MI, Cao A, Pirastu M 1992. A novel $\delta$-thalassemia mutation A $G \rightarrow C$ substitution at codon 30 of the $\delta$-globin gene in a person of southern Italian origin. Hum Mutat 1: 169-171.

Loukopoulos D. 1996. Current status of thalassemia and the sickle cell syndromes in Greece. Semin Hematol 33: 76-86.

Lun FM, Tsui NB, Chan KC, Leung TY, Lau TK, Charoenkwan P, Chow KC, Lo WY, Wanapirak C, Sanguansermsri T, et al. 2008. Noninvasive prenatal diagnosis of monogenic diseases by digital size selection and relative mutation dosage on DNA in maternal plasma. Proc Natl Acad Sci 105: 19920-19925.

Melis MA, Galanello R, Cao A. 1983. $\alpha$ Globin gene analysis in a Sardinian family with interacting $\alpha$ and $\beta$ thalassaemia genes. Br J Haematol 53: 667-671.
Modell B, Darlison M. 2008. Global epidemiology of haemoglobin disorders and derived service indicators. Bull World Health Organ 86: 480-487.

Modell B, Darlison M, Birgens H, Cario H, Faustino P, Giordano PC, Gulbis B, Hopmeier P, Lena-Russo D, Romao L, et al. 2007. Epidemiology of haemoglobin disorders in Europe: An overview. Scand J Clin Lab Invest 67: $39-69$.

Moi P, Paglietti E, Sanna A, Brancati C, Tagarelli A, Galanello R, Cao A, Pirastu M. 1988. Delineation of the molecular basis of $\delta$ - and normal $\mathrm{HbA} 2 \beta$-thalassemia. Blood 72: 530-533.

Moi P, Loudianos G, Lavinha J, Murru S, Cossu P, Casu R, Oggiano L, Longinotti M, Cao A, Pirastu M. 1992. $\delta$ Thalassemia due to a mutation in an erythroid-specific binding protein sequence $3^{\prime}$ to the $\delta$-globin gene. Blood 79: $512-516$.

Monk M, Holding C. 1990. Amplification of a $\beta$-haemoglobin sequence in individual human oocytes and polar bodies. Lancet 335: 985-988.

Myers RM, Fischer SG, Lerman LS, Maniatis T. 1985. Nearly all single base substitutions in DNA fragments joined to a GC-clamp can be detected by denaturing gradient gel electrophoresis. Nucleic Acids Res 13: 3131-3145.

Newton CR, Graham A, Heptinstall LE, Powell SJ, Summers C, Kalsheker N, Smith JC, Markham AF. 1989. Analysis of any point mutation in DNA. The amplification refractory mutation system (ARMS). Nucleic Acids Res 17: 2503-2516.

Old JM, Khan SN, Verma I, Fucharoen S, Kleanthous M, Ioannou P, Kotea N, Fisher C, Riazuddin S, Saxena R, et al. 2001. A multi-center study in order to further define the molecular basis of $\beta$-thalassemia in Thailand, Pakistan, Sri Lanka, Mauritius, Syria, and India, and to develop a simple molecular diagnostic strategy by amplification refractory mutation system-polymerase chain reaction. Hemoglobin 25: 397-407.

Orita M, Iwahana H, Kanazawa H, Hayashi K, Sekiya T. 1989. Detection of polymorphisms of human DNA by gel electrophoresis as single-strand conformation polymorphisms. Proc Natl Acad Sci 86: 2766-2770.

Orofino MG, Argiolu F, Sanna MA, Rosatelli MC, Tuveri T, Scalas MT, Badiali M, Cossu P, Puddu R, Lai ME, et al. 2003. Fetal HLA typing in $\beta$ thalassaemia: Implications for haemopoietic stem-cell transplantation. Lancet 362: $41-42$.

Perseu L, Satta S, Moi P, Demartis FR, Manunza L, Sollaino MC, Barella S, Cao A, Galanello R. 2011. KLF1 gene mutations cause borderline HbA2. Blood 118: 4454-4458.

Phylipsen M, Harteveld CL, de Metz M, Gallivan MV, Arkesteijn SG, Luo HY, Chui DH, Giordano PC. 2010. New and known $\beta$-thalassemia determinants masked by known and new $\delta$ gene defects [ $\mathrm{Hb} \mathrm{A}(2)$-Ramallah or delta6(A3)Glu $\rightarrow$ Gln, GAG $\gg \mathrm{CAG}$ ]. Hemoglobin 34: $445-450$.

Pirastu M, Kan YW, Cao A, Conner BJ, Teplitz RL, Wallace RB. 1983. Prenatal diagnosis of $\beta$-thalassemia. Detection of a single nucleotide mutation in DNA. $N$ Engl J Med 309: 284-287.

Premawardhena A, De Silva S, Arambepola M, Olivieri N, Merson L, Muraco J, Allen A, Fisher C, Peto T, 
Vichinsky E, et al. 2004. Thalassemia in Sri Lanka: A progress report. Hum Mol Genet 13: R203-R206.

Ristaldi MS, Murru S, Loudianos G, Casula L, Porcu S, Pigheddu D, Fanni B, Sciarratta GV, Agosti S, Parodi MI, et al. 1990. The C-T substitution in the distal CACCC box of the $\beta$-globin gene promoter is a common cause of silent $\beta$ thalassaemia in the Italian population. Br J Haematol 74: 480-486.

Rosatelli C, Falchi AM, Scalas MT, Tuveri T, Furbetta M, Cao A. 1984. Hematological phenotype of the double heterozygous state for $\alpha$ and $\beta$ thalassemia. Hemoglobin 8: $25-35$.

Rosatelli MC, Dozy A, Faa V, Meloni A, Sardu R, Saba L, Kan YW, Cao A. 1992. Molecular characterization of $\beta$ thalassemia in the Sardinian population. Am J Hum Genet 50: $422-426$

Saiki RK, Walsh PS, Levenson CH, Erlich HA. 1989. Genetic analysis of amplified DNA with immobilized sequencespecific oligonucleotide probes. Proc Natl Acad Sci 86: 6230-6234.

Samavat A, Modell B. 2004. Iranian national thalassaemia screening programme. BMJ 329: 1134-1137.

Sanger F, Nicklen S, Coulson AR. 1977. DNA sequencing with chain-terminating inhibitors. Proc Natl Acad Sci 74: 5463-5467.

Sankaran VG, Nathan DG. 2010. Reversing the hemoglobin switch. N Engl J Med 363: 2258-2260.

Satta S, Perseu L, Moi P, Asunis I, Cabriolu A, Maccioni L, Demartis FR, Manunza L, Cao A, Galanello R. 2011. Compound heterozygosity for KLF1 mutations associated with remarkable increase of fetal hemoglobin and red cell protoporphyrin. Haematologica 96: 767-770.

Simpson JL, Elias S. 1993. Isolating fetal cells from maternal blood. Advances in prenatal diagnosis through molecular technology. JAMA 270: 2357-2361.

Singleton BK, Burton NM, Green C, Brady RL, Anstee DJ. 2008. Mutations in EKLF/KLF1 form the molecular basis of the rare blood group $\operatorname{In}(\mathrm{Lu})$ phenotype. Blood 112: 2081-2088.

So CC, Chan AY, Luo HY, Verhovsek M, Chui DH, Ling SC, Chan LC. 2011. Hb A2 Hong Kong-A novel $\delta$-globin variant in a Chinese family masks the diagnosis of $\beta$ thalassemia trait. Hemoglobin 35: 162-165.

Sollaino MC, Paglietti ME, Perseu L, Giagu N, Loi D, Galanello R. 2009. Association of $\alpha$ globin gene quadruplication and heterozygous $\beta$ thalassemia in patients with thalassemia intermedia. Haematologica 94: 1445-1448.

Srisupundit K, Piyamongkol W, Tongsong T. 2009. Identification of fetuses with hemoglobin Bart's disease using middle cerebral artery peak systolic velocity. Ultrasound Obstet Gynecol 33: 694-697.
Thein SL. 2008. Genetic modifiers of the $\beta$-haemoglobinopathies. Br J Haematol 141: 357-366.

Thein SL, Menzel S. 2009. Discovering the genetics underlying foetal haemoglobin production in adults. $\mathrm{Br} \mathrm{J} \mathrm{Hae-}$ matol 145: 455-467.

Thein SL, Al-Hakim I, Hoffbrand AV. 1984. Thalassaemia intermedia: A new molecular basis. Br J Haematol 56: 333-337.

Uda M, Galanello R, Sanna S, Lettre G, Sankaran VG, Chen W, Usala G, Busonero F, Maschio A, Albai G, et al. 2008. Genome-wide association study shows BCL11A associated with persistent fetal hemoglobin and amelioration of the phenotype of $\beta$-thalassemia. Proc Natl Acad Sci 105: 1620-1625.

Verlinsky Y, Ginsberg N, Lifchez A, Valle J, Moise J, Strom CM. 1990. Analysis of the first polar body: Preconception genetic diagnosis. Hum Reprod 5: 826-829.

Wainscoat JS, Kanavakis E, Wood WG, Letsky EA, Huehns ER, Marsh GW, Higgs DR, Clegg JB, Weatherall DJ. 1983. Thalassaemia intermedia in Cyprus: The interaction of $\alpha$ and $\beta$ thalassaemia. Br J Haematol 53: 411-416.

Waye JS, Patterson M, Walker L, Eng B, Nakamura LM, Lafferty JD, Yong SL, Wu JK, Chui DH. 2003. $\beta$-Thalassemia in association with a new $\delta$-chain hemoglobin variant $[\delta 116(\mathrm{~g} 18) \mathrm{Arg} \rightarrow$ Leu]: Implications for carrier screening and prenatal diagnosis. Am J Hematol 74: 179-181.

Weatherall DJ. 2010a. The inherited diseases of hemoglobin are an emerging global health burden. Blood 115: 43314336.

Weatherall DJ. 2010b. Thalassemia as a global health problem: Recent progress toward its control in the developing countries. Ann NY Acad Sci 1202: 17-23.

Weatherall DJ, Clegg JB. 2001. The thalassaemia syndromes. Blackwell Science, Oxford.

WHO. 1994. Guidelines for control of haemoglobin disorders. In $W H O / H D P / H B / G L / 941$. WHO, Geneva.

Xu YW, Zeng YH, Deng J, Liu Y, Gao L, Zhou CQ, Zhuang GL. 2009. Preimplantation genetic diagnosis for $\alpha$-thalassaemia in China. J Assist Reprod Genet 26: 399-403.

Zachaki S, Vrettou C, Destouni A, Kokkali G, TraegerSynodinos J, Kanavakis E. 2011. Novel and known microsatellite markers within the $\beta$-globin cluster to support robust preimplantation genetic diagnosis of $\beta$-thalassemia and sickle cell syndromes. Hemoglobin 35: 5666.

Zhou D, Liu K, Sun CW, Pawlik KM, Townes TM. 2010. KLF1 regulates BCL11A expression and $\gamma$ - to $\beta$-globin gene switching. Nat Genet 42: 742-744. 


\section{$\&_{\mathrm{CSH}}^{\infty} \&$ Cold Spring Harbor

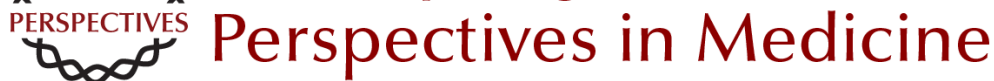

\section{The Prevention of Thalassemia}

Antonio Cao and Yuet Wai Kan

Cold Spring Harb Perspect Med 2013; doi: 10.1101/cshperspect.a011775

Subject Collection Hemoglobin and Its Diseases

The Natural History of Sickle Cell Disease Graham R. Serjeant

Current Management of Sickle Cell Anemia Patrick T. McGann, Alecia C. Nero and Russell E. Ware

Cell-Free Hemoglobin and Its Scavenger Proteins: New Disease Models Leading the Way to Targeted Therapies Dominik J. Schaer and Paul W. Buehler

Clinical Manifestations of $\alpha$-Thalassemia Elliott P. Vichinsky

Erythroid Heme Biosynthesis and Its Disorders Harry A. Dailey and Peter N. Meissner

Hemoglobin Variants: Biochemical Properties and

Clinical Correlates Christopher S. Thom, Claire F. Dickson, David A. Gell, et al.

The Prevention of Thalassemia Antonio Cao and Yuet Wai Kan

The Switch from Fetal to Adult Hemoglobin Vijay G. Sankaran and Stuart H. Orkin
Transcriptional Mechanisms Underlying

Hemoglobin Synthesis

Koichi R. Katsumura, Andrew W. DeVilbiss, Nathaniel J. Pope, et al.

Iron Deficiency Anemia: A Common and Curable Disease Jeffery L. Miller

Management of the Thalassemias Nancy F. Olivieri and Gary M. Brittenham

The Molecular Basis of $\beta$-Thalassemia Swee Lay Thein

Erythropoiesis: Development and Differentiation Elaine Dzierzak and Sjaak Philipsen

Erythropoietin

H. Franklin Bunn

Classification of the Disorders of Hemoglobin Bernard G. Forget and H. Franklin Bunn

The Molecular Basis of $\alpha$-Thalassemia Douglas R. Higgs

For additional articles in this collection, see http://perspectivesinmedicine.cshlp.org/cgi/collection/ 